\title{
Constraints Regarding Green Financing Due to Limited Scope of Capital Requirements in Basel Accord. An Evidence from Development Financial Institutions of Pakistan Dealing in Agricultural Finance.
}

\author{
MIRZA MUHAMMAD ALI BAIG \\ PhD Scholar (Business Administration), Superior University, Lahore, Pakistan. \\ Email: dralibaig514@gmail.com \\ Tel: 03331901449 \\ Dr. NISAR AHMAD \\ Assistant Professor (Commerce), Superior University, Lahore, Pakistan. \\ Email: nisarbazmi71@gmail.com \\ Tel: 03334299033

\section{Dr. NADIA NASIR} \\ Assistant Professor (Business Administration), Superior University, Lahore, Pakistan. \\ Email: nadia.nasir@ superior.edu.pk \\ Tel: 03004170381
}

\begin{abstract}
The aim of this study is to discuss how the stance of a financial institution in associating a green financing can be developed within an ambiance where monetary organizations are facing the challenges of capital requirements by (BA)-III. Basel regulations would not segregate green loans from other financial facilities regarding risk-weightings. The investigators contend that (BA)-III essentials are not supporting the lending facilities of viable financial activities. Zarai Taraqiati Bank Limited-(ZTBL) that plays a vital role in agricultural development sector of Pakistan is examined. The financial institution's capability to increase lending in lieu of green-projects later by the implementation of (BA)-III is engrossed. Investigators explore that whether risk-weightings of green financing stood level down to 49.70 percent from 100, (ZTBL)'s Capital Adequacy Ratio-(CAR) may be 4.5 percent points higher. Ongoing study assumes the riskweightage pertaining green loans need to moderate for ordering to boost up viable progress.
\end{abstract}

Keywords: Sustainable Development Financing-(SDF), Green Banking Loans-(GBL), Financial Institutions-(FI), Basel Accord-(BA), Environment Social and Governance-(ESG), Capital Adequacy Ratio(CAR), Minimum Capital Requirement-(MCR).

\section{Introduction}

According to UNEP, (2016) the Sustainable Financing leads to some kind regarding monetary assistance incorporating (ESG) convention obsessed by the trade rather financing decisions pertaining to durable assistance of both consumers as well as society as a whole. Green Banking Lending-(GBL) is a wide spread terminology that may take to economic investments leading towards sustainable development activities and procedures, ecological products and regulations, which governs growth of extremely viable financial system (Hohne, et al., 2012). Undoubtedly, perspective regarding (GBL) 
differs for various nations; conversely, the less developed nations with adolescent economic systems, facing different challenges in dealing with (GBL). According to Weber, (2013) the relationship between traditional banking as well as sustainable development (SD) started with the green slogan of financial institutions in 1980 s, however certain dedicated, societal and environmental financial institutions had previously commenced during 1970s. Financial Institutions perform a main role in furnishing economical as well as long term lending support for green banking activities. Indeed, financial institutions may face huge risks that take to a failure of economics and monetary disasters. Owing to boost up severity regarding international disasters Basel regulations remained presented in 1988.

According to CISL, UNEP, and FI, (2014) the Basel Committee was approved by the governors of central financial institutions pertaining G10 nations during 1974 later by serious issues occurred in universal currency as well as financial markets. The prime goal of Basel standards s to quantified and examine the Capital Adequacy of the financial institutions and to minimize the severity of international economic disasters, if not preventable. Moreover, Basel standards aim at increasing economic stability by developing the excellence of economic supervision throughout the world, and enhancing efficacious risk administration and trade restraints.

Basel-I stated financial institutions for maintaining a smallest quantity of capital compared to the riskweighted assets (RWAs). During financial year 1999, (BA)-II was announced for catering limitation of (BA)-I regarding onward improving risk-measurement and administration at Financial Institutions. (BA)-II enforced application of risk-weightings for financial institutions to establish riskiness of the financial assets over Standard-1 (MCR). Afterwards, it got practiced that risk weightage regarding majority of financial institutions were weak indicators of the monetary risks to that financial institutions had been exposed. In contrary to the economic disaster of 2007-2008 Basel-III was established. Therefore, Standard-1 of (BA-III) couldn't establish some differences amid financing for (GBL) as well as other corporate financing pertaining to risk weightages. Hence, (GBL) absorb a financial institution's capital as much as other corporate finances. (GBL) might be defined as financial institution's credit distributed for lending viable energy, energy efficacy, progress of agricultural as well as SMEs-Small and medium sized enterprises output. They boost up ecologically liable investments and encourage less carbon technologies, activities, trading, ventures and industries.

That has been observed in various nations that option for (GBL) are insufficient due to restrictions of demand and supply. Keeping in view the perspective of supply side this study debates that without capital requirements for (GBL) are undisturbed, long duration ventures finance for ecologically viable economic undertakings could be constrained. According to Gursoy, (2016) the Basel regulations might support viable growth by establishing risk-weights of (GBL) lesser from certain traditional financings. It might, in-turn minimize capital absorption, preserve Capital adequacy ratio great, and hence galvanize financial institutions regarding passage of capital for ecologically and publically sound ventures.

Yildirim, (2016) states that it is as obvious position that during prevailing time period the pollution due to air and water are fairly intense. It causes wide-ranging financial development on expensing of innate assets along with ecologically issues to endure. As per WEF, 2013 United Nations study forecasted the yearly cost of world's financial system regarding preservation of existing scale of unmanageable financial action may scope to the tune of US Dollar 29.0 trillion by 2050, which may be equal to 17.9 percent of World's GDP (UNEP, 2011). For now, evaluation highlights that approximately US Dollar 1 trillion of supplementary financing in fresh green system in energy, transport, buildings and venture may require on yearly basis till 2030 (WEF, 2013). However, nations need to focus the balance amidst financial growth as well as ecological safety by ranking green growth as a nationwide tactics and presenting different concerned procedures and policies consequently. 
Ongoing study has been structured here under: very first segment comprises of short literature review that evaluates past investigation pertaining to evaluative themes of "Green Banking" as well as "(BA)III". The second segment describes (CAR) in (BA)-III and its impact on (CAR) of Development Financial Institution of Pakistan dealing in Agricultural Finance. Owing to the third segment, the research methodology presented the case study on (ZTBL). The financial institution's capability for enhancing the lending regarding green ventures after (BA-III)'s execution to analyze further. Final segment determines with certain commendations as well as remarks pertaining future investigation.

\section{Review of Literature}

(GBL) incorporates entire economic products and assistance offered regarding promotion of ecologically liable financing and encourage lesser-carbon technologies, ventures, trading, manufacturing, construction and businesses (PWC, NEP, FI, 2014). However, (GBL) are fairly similar to traditional finances. The key variance resides that creditors dispense these finances regarding investing green ventures that usually comprise viable dynamism, energy-efficacy as well as development of agriculture. These finances generically support manufacturing and trading with an optimistic impact on the ecology and culture (IFC, 2016). So far the (ZTBL) case, loans disbursed for economic renewable dynamism, energy efficacy, growth of agriculture and Small and Medium Enterprises productivity are categorized as (GBL).

According to Gursoy, (2016) that the (SD) through (GBL) has to be employed at the center of monetary system. As a matter of information, determinations to establish links amidst economic setup as well as (SD) got recent achievement for reasonable impetus. During Financial year, 2015 as a stance, private financing in renewable dynamics contained almost 67 percent of the net increase regarding world's command capability, and extent of market growth in electric-automobiles enhanced around 61 percent (Bloomberg, 2016). Moreover, viable energy sources have various financial merits to different nations likewise minimization in greenhouse emissions of gasses, modification of energysupplies and minimization in foreign-energy reliance (Akdogan, 2016).

Certainly, financial institutions perform a vital role in investing Sustainable Economic Development(SED). Their structure of capital as well as risk captivating attitude stand important for the general wellbeing of global markets. The submission by means of Basel regulations contributes at the minimum few assurances toward general public as well as their shareholders, they are dreadful for said breakdown. Efficacious execution of (BA-III) would validate to controllers, consumers as well as stakeholders that financial setup stands improving satisfactory from economic disaster pertaining 2007-2008 that is enhancing elasticity towards future crises (Mahapatra, 2012; Erdogdu, 2016). Of course, the performance of monetary controllers need to certify the huge risks, which might intimidate validity of economic setup may not reserve (Gursoy, 2016).

According to Mermod, et al., (2016) this study describes that (BA-III)'s Standard-1 (MCR) dismays economics pertaining ecologically viable financial undertakings. An investigation regarding ecological risks in (BA-III) investigated by the Cambridge University too strived hard for replying the similar query concluded vide interviews relating certain financial institutions senior managers and executives as well as regulators around the globe (CISL \& UNEP FI, 2014; Yildirim et al., 2016). Relied upon interviews, it has determined that the financial and administrative insecurity relating to venture was considerably vital than (BA-III)'s stringent requests of capital in sponsoring green ventures. Certain contenders described too about shrinking capital requirements to assist ecologically viable financial actions could construct a disagreeable exchange between economic stability and ecological viability.

However, the investigators come to an understanding that financial and administrative insecurities of a venture assume a prime aspect in financing conclusions; so, it assumes requirement of capital are equally vital too. Definitely, study described that financial institution's capability for enhancing its 
investment relating green ventures raises, whether requirement of capital is relieved for Green Banking Loan (Gursoy, et al., 2016).

According to Erdogdu, et al., (2016) the investigators concede that insecurity of a (GBL) shouldn't be ignored. Furthermore, proposed a dissimilarity amidst (GBL) as well as other traditional financing on account of Risk-Weightings-(RWs) ought to be done, and risk-weights of (GBL) need to be minimized by controllers. It could motivate financial institutions for supporting a greener-economy as their (CAR)s would be lesser influenced from disbursing the advances.

\section{Debates on (BA)-III and its Consequences}

Basel Commission got functional due to chief financial institutions authorities of the G10-Nations during 1974 later by severe issues got proficient in global currency as well as economic marketplaces. Major goal of Basel standards requires to compute as well as examine (CAR) pertaining financial institutions and to minimize severity regarding international monetary disasters, whether not ignorable (CISL and UNEP FI, 2014, Gursoy, et al., 2016). Moreover, Basel standards aim at increasing monetary steadiness by increasing excellence concerned with financial command globally and enhancing effective-risk administration as well as market norms.

(BA-I) got implemented during 1998 that specified globally financial institutions should detain a least sum of capital in case of their Risk Weighted Assets-(RWAs). It is aiming onto promotion of global level playing field for cross border economics (Norton, 1995). In reality, (BA-I) attained the goal of enhancing sum of supervisory capital pertaining financial institutions; though, it comprised various nationwide preferences, gaps as well as enticements regarding financial institutions to establish riskier short-run advances and to relocate lesser risky-assets off the statement of affairs (Goodhart, 2011).

(BA-II) was proposed during 1999 for catering gaps of (BA-I) and maintained the "Three-Standards" strategy namely Minimum-Capital, Supervisory-Review and Market-Discipline. So the three key Standards constructed to back up one another and to induce financial institutions to enhance their risk measurement and administration. (BA)-II stressed the application of risk-weightings for financial institutions to establish the riskiness of their financial assets through Standard-I that is (MCR). Financial Assets with lesser (RWs) usually draw lesser Capital Charges-(CCG), wherein assets with high (RWs) normally draw high (CCG).

Furthermore, it got practiced that (RWs) regarding various financial institutions were weak indicators pertaining monetary risk with which monetary organizations got visible. Basel Commission rejoined to 2007-2008 monetary disasters by amending (BA-II) that got recognized as (BA-III). Though, (BAIII) is not officially obligatory, various nations got accepted it. Certain nations select some requirements to observe accordingly, whereas some execute severer regulations. Pakistani financial institutions have almost adopted (BA)-III capital restrictions from 2014 and comprehensive execution would be operational from January, 2019, according to the suitability of their developing market counterparts. Therefore, capital risk weight-(CRW) of advances, (BA)-III capital requirements and the influence of (BA)-III on (CAR)s of Pakistani financial institutions are described in upcoming segments. (BA)-III doesn't distinguish (GBL) from other Standard-I of the (BA-III), which may not make any distinguish between advances for Green Ventures and other Traditional loans regarding (RWs).

Owing to the prevailing study, its contended that lest (CRW) are peaceful, long run project lending regarding ecologically viable financial actions could be constrained. Investigators consider that Basel regulations might bear viable improvement by establishing risk weights of (GBL) lesser from other corporate finances. It might, successively minimize capital consumption, keeping Capital Adequacy Ratios high, and then incentivize financial institutions to channelize their capital to ecologically and 
culturally sound ventures. Pakistani financial institutions apply on to the public ratings of "Fitch Ratings International Ratings Institutions-FRIRI” in ascertaining (RWs) of finances.

Appended below tabulation reveals risk-weights of various credit classifications that is dealing with (BA-III) principles and native financial standards. That's assume from appended tabulation that Basal regulations do not make any variance between (GBL) and other traditional loans in terms of $(\mathrm{CRW}) \mathrm{s}$. Pakistan's rating is considered B- having stable outlook as per observation of Standard \& Poor's credit agency. Moody's shows the credit rating of Pakistan as B3 with sound stance. (Fitch Rating, 2020). Conversely, ZTBL adopts the rating standard of Medium to Long run rating as "AAA" means high credit excellence with minimum risk factors. However, the rating scale would be "A-1+" for short run; and its deems high level certainty of in-time payment, liquidity-factors are exceptional and safety is comparatively lower from risk free shot-run commitments of Pakistan's Government. Traditional loans have 99.99 percent risk weight in development financial institutions dealing in agricultural finance regardless of the type, security, ageing or possibility of default. It apparently limits the whole appetite of financial institutions for disbursing venture financings to declare the green-project sponsoring credits.

Moreover, the negative supply influence, this too takes to lesser demand for ventures due to higher cost of sponsoring as financial institutions pass on the complete charge on their capital to debtors by setting high level of mark-up rates on venture finance. The investigators proposed that (CR) for (GBL) ought to be eased to enhance the supply of long run project finance regarding ecologically viable financial actions and thus establishing them comparatively reasonable pertaining to debtors on account of costing (Gursoy, 2016).

Table-I. Capital (RWs) by Loan Segments and Allocated Rating Standards

\begin{tabular}{|c|c|c|c|c|c|c|}
\hline \multirow{3}{*}{$\begin{array}{c}\text { Credit } \\
\text { Excellence } \\
\text { Ranks }\end{array}$} & \multirow{3}{*}{ Risk Rating } & \multirow{3}{*}{$\begin{array}{l}\text { Disclosure } \\
\text { to SBP }\end{array}$} & \multicolumn{3}{|c|}{ Disclosure Categories } & \multirow{3}{*}{$\begin{array}{l}\text { Corporate } \\
\text { Receivable }\end{array}$} \\
\hline & & & \multirow{2}{*}{$\begin{array}{l}\text { Disclosure } \\
\text { to Non- } \\
\text { Commercial } \\
\text { Holdings }\end{array}$} & \multicolumn{2}{|c|}{$\begin{array}{c}\text { Disclosure to Financial } \\
\text { Institutions and } \\
\text { Brokerage Houses } \\
\end{array}$} & \\
\hline & & & & $\begin{array}{l}\text { Remaining } \\
\text { Maturities } \\
\text { Less Than } \\
3 \text { Months }\end{array}$ & $\begin{array}{l}\text { Continuing } \\
\text { Maturities } \\
\text { More Than } \\
\text { 3 Months }\end{array}$ & \\
\hline 1 & $\begin{array}{c}\mathrm{AA}- \\
/ \mathrm{AA} / \mathrm{AA}+/ \mathrm{AAA} \\
\end{array}$ & $0 \%$ & $20 \%$ & $20 \%$ & $20 \%$ & $20 \%$ \\
\hline 2 & $\mathrm{~A}-/ \mathrm{A} / \mathrm{A}+$ & $20 \%$ & $50 \%$ & $20 \%$ & $50 \%$ & $50 \%$ \\
\hline 3 & $\begin{array}{c}\text { BBB- } \\
/ \mathrm{BBB} / \mathrm{BBB}+\end{array}$ & $50 \%$ & $100 \%$ & $20 \%$ & $50 \%$ & $100 \%$ \\
\hline 4 & BB-/BB/BB+ & $100 \%$ & $100 \%$ & $50 \%$ & $100 \%$ & $100 \%$ \\
\hline 5 & $\mathrm{~B}-/ \mathrm{B} / \mathrm{B}+$ & $100 \%$ & $100 \%$ & $50 \%$ & $100 \%$ & $100 \%$ \\
\hline 6 & $\begin{array}{c}\mathrm{C} / \mathrm{CC} / \mathrm{CCC}- \\
\mathrm{CCC} / \mathrm{CCC}+/ \mathrm{D}\end{array}$ & $100 \%$ & $100 \%$ & $150 \%$ & $100 \%$ & $100 \%$ \\
\hline
\end{tabular}

Source: (State Bank of Pakistan, 2020 at https://www.sbp.org.pk/bsrvd/2007/Annex_CL9.pdf.)

\section{Capital Aspects Tight Going-Forward}

Pakistani financial institutions have commenced to accept (BA-III) Capital Requirements-(CRs) from financial year 2014 and the comprehensive execution would be effective from January, 2019 as is the matter in various counterparts of the developing nations. The investigators assume that various Pakistani financial institutions require capital in the short run to fulfil (BA)'s requirements during 2019. Owing to (BA-III), the Minimum Common Equity Tier-I (CET-1) advices were established at 4.5 percent of Risk Weighted Assets and a supplementary Tier-1 of 1.5 percent got identified causing in a Tier-1 capital of 6.0 percent of Risk Weighted Assets (SBP, 2019). 
During FY-2016, some safety buffers have been maintained rising gradually till 2019 and later on. The "Capital Conservation Buffer-(CCB)" was established as 0.625 percent for the first year with effect from January, 2016 that would gradually increase to 2.5 percent till January, 2019. Moreover, the "Systemic Risk Buffer-(SIFI)" was established that permits the financial regulator to impose a capital surcharge of up to 3 percent of Risk Weightage Assets for those financial institution it believes scientifically vital. The SBP classified the organized significance of Pakistani financial institutions into three categories that is (Category-1: 1 percent; Category-2: 1.5 percent; Category-3: 2.0 percent) whereas big financial institutions in the system are categories under Category-3 and will segment in the D-SIB, commencing at 0.5 percent and climbed to 2 percent by the end of financial year 2019 .

Contrary to, the financial regulator has established the "Countercyclical Buffer-(CCyB)" at 0 percent identifying the main parameter that may lead the execution of this buffer as the "Credit-to-GDP Gap" (that is the difference between the Credit-to-GDP ratio and its long run tendency). It the Credit-toGDP gap in the Pakistani financial setup exceed 3 percent (the prerequisite is severer at 2 percent under BA-III), a (CCyB) would be presented, the ceiling of that would be 2.5 percent. Overall with the addition of capital conservation and scientifically significant financial institutions buffers, the core Tier-1 capital and Tier-1 capital approach would reach to 9 percent and 10.5 percent for big financial institutions during 2019 excluding the (CCyB) that would currently fix at 0 percent (SBP, 2019).

Table-II. Pakistani Financial Institutions-Capital Threshold (2016-2019)

\begin{tabular}{|l|c|c|c|c|}
\hline CET1 & $\mathbf{2 0 1 6}$ & $\mathbf{2 0 1 7}$ & $\mathbf{2 0 1 8}$ & $\mathbf{2 0 1 9}$ \\
\hline Overall threshold & $\mathbf{5 . 5 \%}$ & $\mathbf{6 . 7 \%}$ & $\mathbf{7 . 8 \%}$ & $\mathbf{9 . 0 1 \%}$ \\
Minimum & $4.6 \%$ & $4.4 \%$ & $4.4 \%$ & $4.51 \%$ \\
Conservative Buffer & $0.7 \%$ & $1.4 \%$ & $1.89 \%$ & $2.51 \%$ \\
Counter Cyclical Buffer & $0.0 \%$ & $0.0 \%$ & $0.0 \%$ & $0.0 \%$ \\
SIFI Buffer & $0.6 \%$ & $1.0 \%$ & $1.51 \%$ & $2.01 \%$ \\
\hline Tier-I & $\mathbf{2 0 1 6}$ & $\mathbf{2 0 1 7}$ & $\mathbf{2 0 1 8}$ & $\mathbf{2 0 1 9}$ \\
\hline Overall threshold & $\mathbf{7 . 2 \%}$ & $\mathbf{8 . 2 \%}$ & $\mathbf{9 . 3 9 \%}$ & $\mathbf{1 0 . 5 1 \%}$ \\
Minimum & $5.9 \%$ & $5.9 \%$ & $6.01 \%$ & $6.01 \%$ \\
Conservation Buffer & $0.7 \%$ & $1.29 \%$ & $1.91 \%$ & $2.49 \%$ \\
Counter Cyclical Buffer & $0.0 \%$ & $0.0 \%$ & $0.0 \%$ & $0.0 \%$ \\
SIFI Buffer & $0.49 \%$ & $1.01 \%$ & $1.51 \%$ & $1.99 \%$ \\
& & & & \\
\hline CAR & $\mathbf{2 0 1 6}$ & $\mathbf{2 0 1 7}$ & $\mathbf{2 0 1 8}$ & $\mathbf{2 0 1 9}$ \\
\hline Overall threshold & $\mathbf{9 . 2 \%}$ & $\mathbf{1 0 . 2 9 \%}$ & $\mathbf{1 1 . 3 9 \%}$ & $\mathbf{1 2 . 5 1 \%}$ \\
Minimum & $7.9 \%$ & $8.01 \%$ & $7.9 \%$ & $7.99 \%$ \\
Conservation Buffer & $0.6 \%$ & $1.4 \%$ & $1.89 \%$ & $2.51 \%$ \\
Counter Cyclical Buffer & $0.0 \%$ & $0.0 \%$ & $0.0 \%$ & $0.0 \%$ \\
SIFI Buffer & $0.49 \%$ & $1.01 \%$ & $1.51 \%$ & $1.99 \%$ \\
\hline
\end{tabular}

Source: (State Bank of Pakistan, 2020 at https://www.sbp.org.pk/bsrvd/2007 bsrvd/2007/CL2.htm)

\section{RWA progress might be under stress}

Later by 2012, the (CAR) and Tier-I capital ratios have already declined as much as 200bps and 130bps through severe erosion in available for sale securities reserves and the enhancement in (RWAs). Additionally, as elaborated above, (BA-III) is predictable to extra ordinary stress on (CAR). Unconsolidated (CAR) and Tier-I capital ratios of Pakistani development financial institutions dealing in agricultural finance averaged at 15.99 percent and 13.9 percent as of September, 2016 and are contentedly above the thresholds. That being mention, leading to stricter capital standards, Pakistani financial institutions may ponder upon capital efficacy, Risk Weightage Assets optimization and more gainful sections to preserve capital. 
Certainly, those with resilient Tier-I capital ratios might be comparatively feasible supporting the loan growth tactics and may have additional time period for enhancing capital efficiency and Risk Weightage Assets optimization. With capital thresholds projected to increase 4.49 percent points until the end of 2019 along with the phasing-in procedures of safety buffers, certain Pakistan financial institutions may doubtfully endure their historical development rates going-forward. This might also assume the financial institutions would be lesser reassuring of the overall national financial system as well. Risk Weightage Assets are anticipated growing at a sluggish pace than in the post global disaster period. In the meantime, the development in core capital might understood the enhancement in Risk Weightage Assets on average, owing to sluggish enhancement in retained earnings (Fitch Ratings).

Figure-I. Pakistani Financial Institutions-(CAR)

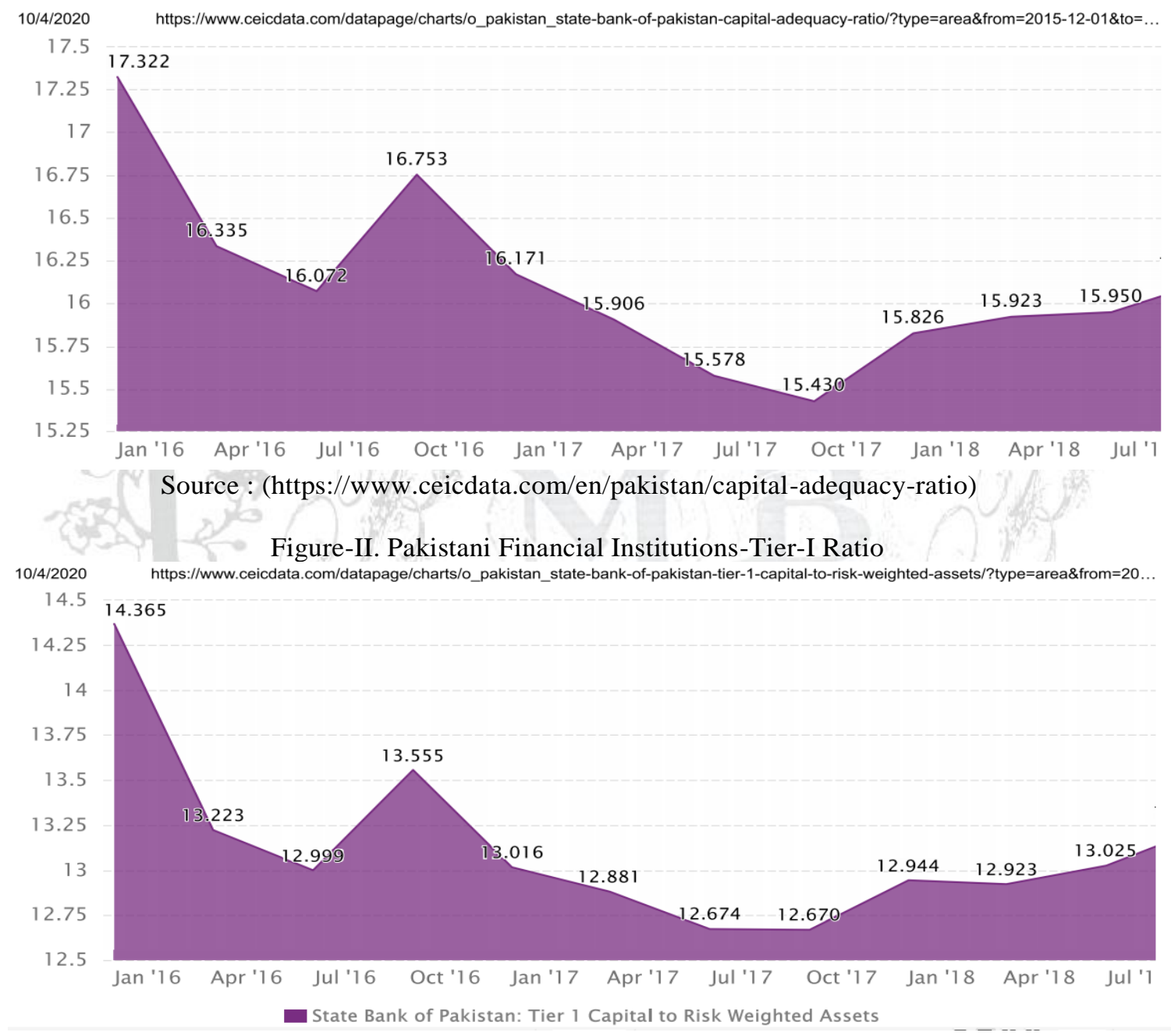

Source: (https://www.ceicdata.com/datapage/charts/o_pakistan_state-bank-of-pakistan-tier-1-capitalto-risk-weighted-assets/?type $=$ area\&from=2015-12-01\&to=2018-09-01\&lang=en)

This may be concluded out of above referred debate that financial institutions capability to increase lending for (GBL) after (BA-III) execution set to weaken as their (CAR)s are under stress. Unless (CRs) for (GBL) are eased by native government bodies, long run project loaning for ecologically viable financial activities would be restricted and chances for (GBL) likewise sustainable dynamics, energy efficiency, growth of agriculture and Small and Medium Enterprises yield could be in 
difficulty. Investigators defined that indigenous administrations ought to aim at encouraging more financing in (GBL) and better loaning for ecologically viable financial activity (Standard \& Poor, 2017).

\title{
Methodology of Research
}

In this segment, the case study technique has been applied to proposed that (BA-III) requirements connected to (RWs) of (GBL) ought to be soften regarding encouraging viable growth. (ZTBL), which a leading development financial institution of Pakistan dealing in Agricultural Finance as well as microfinance lending model and dispenses an important part of its financing portfolio to viable development loans is investigated as a case. (ZTBL)'s capability to enhance its loaning for green loans such viable dynamic, energy efficiency, agricultural growth and Small and Medium Enterprises productivity later by (BA-III)'s execution is observed. The sensitivity of (ZTBL)'s Capital Adequacy Ratio to modify in risk weighting of $(\mathrm{GBL})$ is examined any further. Investigators attempt to determine whether the financial institutions capability to enhance its lending for (GBL) later by (BAIII)'s execution might be enhanced by minimizing risk weights for (GBL).

\section{Brief about ZTBL}

The development financial institution has an equity of Rs. 12,522 Million, asset size to Rs. 215,561 Million and loans of Rs. 135,765 Million as of December, 2016. While reviewing the composition of assets and liabilities (Figure-III), it seems that Mark-up to the tune of 14,176 Million on overall financial assets. On the contrary, the loan categories (Figure-IV), the General Credit for Various Items comprise of 43.91 percent followed by Kissan Dost Scheme 19.89 percent. Henceforth, development loans are in the line with the mission of ZTBL as the sponsor of micro businesses, agriculture and Small and Medium Enterprises (ZTBL, 2020).

Figure-III. Assets \& Liabilities Mix

\section{Financial Performance of ZTBL FY-2016}

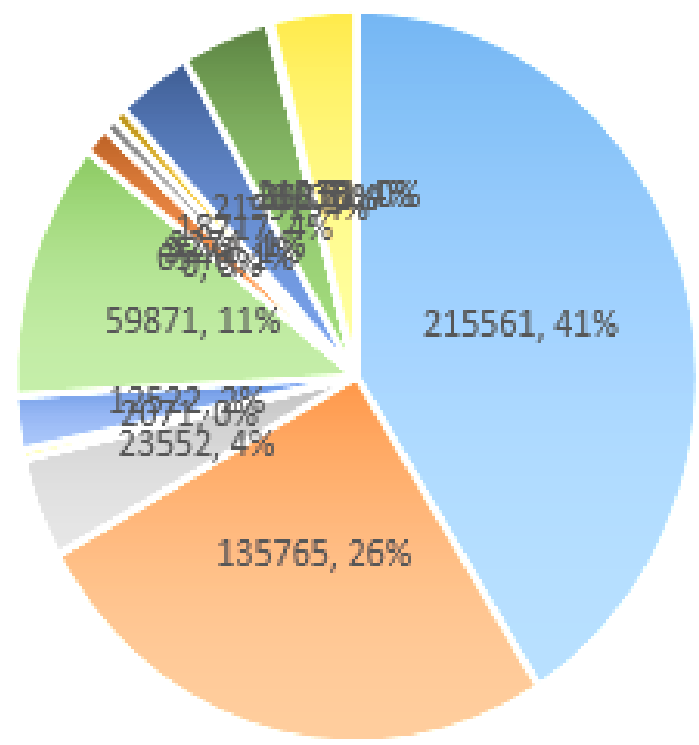

\author{
- Total Assets
}

Advances-net

- Cash \& Bank Balance

Source: (Directors Report, December, 2016 ZTBL at www.ztbl.com.pk) 
Owing to Capital Adequacy, ZTBL's (BA-III) compliant (CAR) fixes at 10.65 percent as of December, 2016 and Tier-I ratio at 7.50 percent points till December, 2016, and the phase-in procedure of safety buffers, minimum (CAR) would be 12.5 percent and minimum Tier-I at 10.5 percent for development financial institutions in Pakistan. Undoubtedly, the current (CAR) and Tier-I ratios of ZTBL are moderately lower the minimum thresholds set by (BA-III). However, the key concern is the financial institution's capability to enhance its lending for (GBL) after (BA-III) execution. Owing to stricter capital standards, ZTBL has to emphasis more on Capital efficacy, Risk Weightage Assets optimization and more gainful sectors to preserve capital. The financial institutions could be less contended supporting the loan development; however, its loaning for viable growth ventures may be constraints (ZTBL, 2020).

Figure-IV. ZTBL Loan Mix

\section{Scheme-wise Disbursement}

\begin{tabular}{|c|c|c|}
\hline & $0.02 \%$ & $5.64 \%$ \\
\hline & $0.05 \%$ & $0.08 \%$ \\
\hline & $0.55 \%$ & $0.08 \%$ \\
\hline & $0.13 \%$ & $=0.02 \%$ \\
\hline & $0.11 \%$ & \\
\hline 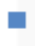 & Sada Baha & ar Scheme \\
\hline 口 & Kissan Dos & st Scheme \\
\hline 口 & Karachi Pa & ackage \\
\hline - & Asan Qarzi & a Scheme \\
\hline - & Khushk Ra & atab Scheme \\
\hline - & Tahafuz-e- & Ajnas Scheme \\
\hline - & Red Meat $\mathrm{F}$ & Financing Package \\
\hline 口 & General $\mathrm{Cr}$ & redit for various Item \\
\hline
\end{tabular}

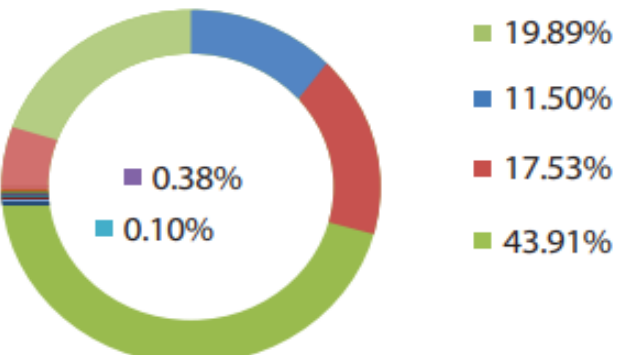

Source: (Directors Report, December, 2016 ZTBL at www.ztbl.com.pk)

\section{Research Results}

Loans disbursed for sponsoring viable dynamics, energy efficiency, agricultural growth and Small and Medium Enterprises productivity are categorized as (GBL) in this investigation. Conferring to ZTBL's viability report as of 2016, around 71 percent funds acquired from donor agencies from foreign and local markets regarding financing microfinance as well as agriculture credit needs, trade and Small and Medium Enterprises. It really gives a significant insight pertaining to the funding structure of financings. For the sake of investigation, it is conventionally assumed that more than 65 percent of loans are used for (GBL) by ZTBL. Resultantly, if (RWs) of ((GBL)s) were fallen to 55 percent from 100 percent, ZTBL's (CAR) would be almost 1.85 percent point lower and it might partially counterbalance the strictness of (BA-III) on the financial institution's capital. Outcome of the analysis further stimulates us to proposed that (BA-III)'s requirements concerned with (RWs) of (GBL) ought to be contended in order to inspire viable growth. It might, in-turn, minimize capital use-ability, keeping Capital Adequacy Ratios and thus incentivize of financial institutions to channel their capital to ecologically and ethically stable ventures. 
Table-III. Sensitivity Analysis of ZTBL's (CAR)

\begin{tabular}{|c|c|c|c|c|c|}
\hline \multicolumn{3}{|c|}{ Rupees in thousand, unless otherwise stated } & $\begin{array}{c}\text { Current } \\
\text { 100\% Risk } \\
\text { Weight } \\
10.65 \% \\
7.50 \%\end{array}$ & 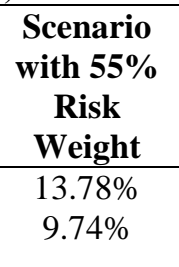 & $\begin{array}{c}\text { (CAR) } \\
\text { support } \\
\text { from lower } \\
\text { risk weight }\end{array}$ \\
\hline $\begin{array}{l}\text { (III+II- } \\
\text { VI)/VIII }\end{array}$ & $\begin{array}{l}\text { I } \\
\text { II } \\
\text { III } \\
\text { IV } \\
\text { V } \\
\text { VI } \\
\text { VII } \\
\text { VIII } \\
\text { IX } \\
X \\
\text { XI }\end{array}$ & $\begin{array}{l}\text { CAR } \\
\text { Tier-I } \\
\text { Tier-I Capital } \\
\text { Deduction from Tier-I Capital } \\
\text { Net Tier-I Capital } \\
\text { Tier-II Capital } \\
\text { Total Capital } \\
\text { Deduction from Total Capital } \\
\text { RWA } \\
\text { Total Loans } \\
\text { Traditional Loans } \\
\text { Green Financing } \\
\text { Risk-weighted Traditional Loans }\end{array}$ & $\begin{array}{c}10.65 \% \\
7.50 \% \\
77040 \\
648 \\
76392 \\
10485 \\
87525 \\
324 \\
18554599 \\
135,765,150 \\
88247348 \\
47517803 \\
47517803\end{array}$ & $\begin{array}{c}13.78 \% \\
9.74 \% \\
77040254 \\
648359 \\
76392251 \\
10485322 \\
87525254 \\
324596 \\
14357315 \\
135765021 \\
88247348 \\
47517805 \\
23758904\end{array}$ & $\begin{array}{l}3.14 \% \\
2.18 \%\end{array}$ \\
\hline
\end{tabular}

\section{Conclusion and Discussion}

As banking regulators are examining regulations and policies to pledge economic stability and well grooming economy, they ought to aim at encouraging more financing in green loans. This article has revealed that (BA-III)'s Standard-I (MCR) discourages the sponsoring of ecologically viable financial activities by minimizing financial institutions capability to enhance loaning for green ventures. ZTBL, which is leading microfinance as well as agricultural credit institution model in government sector of Pakistan is ascertained in this study. The financial institutions are anticipated to be lesser contended supporting the financial development and its sponsoring for sustainable development ventures might be constrained due to requirement of (BA-III).

Owing to the investigation, it is revealed that if (RWs) of (GBL) were fallen to 55 percent from 100 percent, ZTBL's (CAR) might be around 4 percent points greater and this might partially counterbalance the stress of (BA-III) on the financial institutions capital. Hence, the financial institutions capability for (GBL) likewise sustainable energy, energy-efficacy, development of agriculture and Small \& Medium Enterprises output might increase. On the back of our investigation, the study proposed that (BA-III) requirements concerned with (RWs) of (GBL) ought to be comfortable ordering thereby encouraging viable growth. This might in turn minimizing capital useability, keeping (CAR)s greater and thus motivate financial institutions to channel their capital to ecologically and culturally stable venture. Our investigation clearly has profound execution. Furtherance to that study it is important to examine the viability of its execution. Fat of the matter, in this study only one Pakistani development financial institutions dealing in Agricultural Finance is investigated (Gursoy, et al., 2016).

ZTBL is a medium level Pakistani development financial institution dealing in agricultural finance to the farmers on account of its size of assets. Owing to that purpose, it does not symbolize the whole Pakistani banking setup. Furtherance to that this study may emphasis on large scale financial institutions functioning in Pakistan or various regions around the globe. This establishes a limitation of this study. Moreover, the viability impact of disbursing (GBL) is not deemed in this study. The investigators stress only on the capital adequacy effect and risk weights of (GBL). A future study 
might be conducted on gain-ability by gathering data on costs, benefits and assets excellence tendencies of green credits.

\section{References}

Akdogan, D. A. (2016). European Union Renewable Energy Policy. In Proceedings of International Sustainability Congress in Istanbul, Turkey (vol. 1, pp. 35-36). London, UK: IJOPEC Publication.

BRSA. (2016). Regulation on Measurement and Assessment of Capital Adequacy Ratios of Banks. Banking Regulation and Supervision Agency. Online available at http://www.bddk.org.tr/WebSitesi/turkce/Mevzuat/Bankacilik_Kanununa_Iliskin_Duzenlemeler/1 5068syr_ek_1_09_12_2016_degisiklik_isleme.pdf

Chawla, S., 2002. Developments in Pakistan economy post. Strategic Analysis.

CISL \& UNEP FI. (2014). Stability and Sustainability in Banking Reform: Are Environmental Risks Missing in Basel III. The University of Cambridge Institute for Sustainability Leadership \& United Nations Environment Program Finance Initiative. Online available at http://www.unepfi.org/fileadmin/documents/StabilitySustainability.pdf

Fitch Rating, 2020. Online available at https://www.fitchratings.com/research/islamic-finance/fitchaffirms-pakistan-at-b-outlook-stable-17-08-2020\#: :text=Fitch\%20Ratings\%20\%2D\%20 Hong\%20Kong\%20\%2D\%2017,\%2D'\%20with\%20a\%20Stable\%20Outlook.

Goodhart, C. (2011). The Basel committee on banking supervision: A history of the early years, 19741997. Cambridge, UK: Cambridge University Press.

Gursoy, O., Erdogdu, M.M., Mermod, A., Y., Yildirm, O. B. A., 2016. Do Capital Requirements in Basel III Restrict the Financing of Green Economy? A Case Study of a Turkish Bank. Social and Economic Perspectives on Sustainability. Online available at ijopec.co.uk.

Hohne, N., Khosla, S., Fekete, H., \& Gilbert, A. (2012). Mapping of Green Finance Delivered by IDFC Members in 2011. Online available at https://www.kfwentwicklungsbank.de/migration/EntwicklungsbankStartseite/Entwicklungsfinanzierung/Umweltund-Klima/Zahlen-Daten-Studien/Studien-undPublikationen/2012_Mapping-Report.pdf

Hoque, M. M., Bakar., Talukder, A., 2015. Green Banking Initiatives of Some Selected PCBs in Bangladesh: A Special Focus on Islami Bank Bangladesh Limited. International Journal of Ethics in Social Sciences Vol.3, No. 1

Ibe-enwo, G., Igbudu, N., Garanti, Z., Popoola, T., 2019. Assessing the Relevance of Green Banking Practice on Bank Loyalty. The Mediating Effect of Green Image and Bank Trust. Sustainability.

IFC. (2016). Greening the Banking System - Experiences from the Sustainable Banking Network. International Finance Corporation. Online available at http://www.ifc.org/wps/wcm/connect/712ae885-5985-4fa4-9c27a089f84f4ab7/SBN_PAPER_G20_3rd+draft_updated.pdf?MOD=AJPERES

Islam, M.S., Das, P.C., 2013. Green Banking practices in Bangladesh. IOSR Journal of Business and Management. Volume 8, Issue 3 (Mar. - Apr. 2013), PP 39-44

Javeria, A., Siddiqui, S.H., Rasheed, R., 2019. Towards Green Banking in Pakistan: Problems, Players and Prospects. Pakistan Journal of Social Sciences (PJSS) Vol. 39, No. 2, pp. $363-376$

Julia, T., Kassim, S., 2020. Green Banking. Banking and Finance. IIUM Institute of Islamic Banking and Finance (IIBBF), IIUM, Kuala Lumpur, Malaysia. IntechOpen.

Khan, Y., Szegedi, K., 2019. THE CONCEPT OF GREEN BANKING IN PAKISTAN. Sarhad Journal of Management Sciences (SJMS). Vol. 5, Issue 2

Lalon, R.M., 2015. Green banking: Going green. International Journal of Economics, Finance and Management Sciences Vol. 3 No. 1, PP. 34-42

MacDonald, J.(2016). Electric vehicles to be 35\% of global new car sales by 2040. Online available at http://about.bnef.com/press-releases/electric-vehicles-to-be-35-of-global-new-car-sales-by-2040

Mahapatra, B. (2012). Implications of Basel III for capital, liquidity and profitability of banks. Speech given at the National Conference on Emerging Macro Environment, Regulatory Changes and Bank Competitiveness. Pune, India. Online available at http://www.bis.org /review/r120305b.pdf 
N., 2011. Sustainable Green Banking Approach: The Need of the Hour. Business Spectrum. Volume-I, No.1.

Norton, J. J. J. (1995). Devising international bank supervisory standards. London: Graham \& Trotman.

Gursoy, G., Erdogddu, M.M., Mermod, A.Y., Yildirim, O.B.A., (2016). Social and Economic Perspectives on Sustainability, IJOPEC Publication, Istanbul.

Pusva, I.D., Herlina, E., 2017. Analysis of the implementation of green banking in achieving operational cost efficiency in the banking industry. The Indonesian Accounting Review Vol. 7, No. 2.

PWC CN. (2014). Exploring Green Finance Incentives in China. Price water house Coopers Consultants. Online available at http://www.pwccn.com/home/eng/green_finance _incentives_oct2013.html.

Rauth, B., Malhotra, B.A., 2013. Green Banking Strategies: Sustainability through Corporate Entrepreneurship. Greener Journal of Business and Management Studies Vol. 3 (4), pp. 180-193.

Sekerbank. (2013). Sekerbank Sustainability Report. Online available at http://www.sekerbank.com.tr/docs/default-source/english_doc/sustainabilityreport2013.pdf?sfvrsn=8.

Singh, S., 2016. Green Banking Practices and Their Impact to Reduce Stress in Public Sector Banks. Indian Journal of Applied Research. Vol. 6, No. 4.

$\begin{array}{llllll}\text { Standard } & \text { P } & \text { Poors, } & \text { Online } & \text { available }\end{array}$ https://www.standardandpoors.com/en_US/web/guest/home.

State Bank of Pakistan, 2017. Green Banking Guidelines. Issued vide IH\&SMEFD Circular \# 08 dated October $09 . \quad$ Online available at file:///D:/Green\%20Banking/Pakistan_GreenBankingGuidelines_October2017.pdf.

Shaumya, Arulrajah, K., A., 2017. The Impact of Green Banking Practices on Bank's Environmental Performance: Evidence from Sri Lanka. Journal of Finance and Bank Management June. Vol. 5, No. 1, pp. 77-90

Trading Economics, (2019). Available online at, https://tradingeconomics.com/pakistan/rating.

Ullah, M.M., 2013. Green Banking in Bangladesh- A Comparative Analysis. World Review of Business Research Vol. 3. No. 4.

UNEP. (2016). Green Finance for Developing Countries: Needs, Concerns and Innovations. United Nations Environment Programme. Online available at

http://www.sustainablefinance.ch/upload/cms/user/201607_Green_Finance_for_Developing_Countrie S_UNEP.pdf.

UNEP FI. (2011). Universal Ownership: Why environmental externalities matter to institutional investors. United Nations Environment Program Finance Initiative. Online available at http://www.unepfi.org/fileadmin/documents/universal_ownership_full.pdf.

Weber, O. (2015). The banking sector's contribution to sustainable growth risk assessment, sustainable finance, voluntary initiatives and regulations. SSRN Electronic Journal. doi:10.2139/ssrn.2658348

VIS Credit Rating Company, 2020. Online available at https://nation.com.pk/23-Jul-2020/visreaffirms-entity-rating-of-ztbl-at-aaa-a-1

Weber, O. (2013). Measuring the impact of socially responsible investing. SSRN Electronic Journal. doi:10.2139/ssrn.2217784

WEF. (2013). The Green Investment Report - The ways and means to unlock private finance and green growth. World Economic Forum. Retrieved November 5, 2016, from http://www3.weforum.org/docs/WEF_GreenInvestment_Report_2013.pdf

Zarai Taraqiati Bank Limited, 2020. Online available at https://www.ztbl.com.pk/annual_report/2016/pdf. 